\title{
ANALISIS PERBANDINGAN LAPORAN ARUS KAS BANK YANG MEMBAYAR DIVDEN DENGAN YANG TIDAK MEMBAYAR DIVIDEN PADA BANK YANG TERDAFTAR DIBURSA EFEK INDONESIA
}

\author{
Mutia Farina Sihotang \\ Romasi Lumban Gaol
}

\begin{abstract}
Abstrak
Tujuan penelitian adalah untuk mengetahui apakah ada perbedaan arus kas antara bank yang membayar dividen dengan bank yang tidak membayar dividen pada Bank yang terdaftar di Bursa Efek Indonesia tahun 2009. Berdasarkan penelitian terdahulu diketahui bahwa sebagian Bank tetap melakukan pembayaran dividen meskipun arus kas operasional dan investasi negatif, tetapi ada juga Bank yang tidak membayar dividen sekalipun memiliki arus kas operasi dan investasi yang positif. Populasi penelitian adalah seluruh perusahaan perbankan yang tedaftar di Bursa Efek Indonesia tahun 2009 yakni sebanyak 29 perusahaan, sehingga penentuan sample dalam penelitian menggunakan metode total sampling yakni menggunakan seluruh populasi menjadi sample penelitian. Berdasarkan hasil uji beda, diperoleh nilai signifikansi arus kas operasi adalah 0.774 dan nilai signifikansi arus kas investasi sebesar 0.580, dimana keduanya lebih besar dari 0.05. Hal ini menunjukkan bahwa tidak ada perbedaan yang signifikan arus kas dari aktivitas operasi dan aktivitas investasi antara bank yang membayar dividen dengan bank yang tidak membayar dividen pada Bank yang terdaftar di Bursa Efek Indonesia (BEI). Hal ini diindikasikan oleh nilai sig-p Levene Test $>0.05$. jika diuji dengan regresi logistik diperoleh hasil 0.447 jika diuji secara simultan, secara parsial diperoleh hasil 0.780 untuk aktivitas operasi dan 0.585 untuk aktivitas investasi dan semuanya lebih besar dari 0.05 , hal ini berarti tidak ada pengaruh laporan arus kas terhadap pembayaran dividen.
\end{abstract}

Kata kunci : Arus Kas Operasi, Arus Kas Investasi, dan Pembayaran Dividen

\section{PENDAHULUAN}

Laporan keuangan merupakan salah satu alat yang digunakan manajemen untuk menarik calon investor. Laporan keuangan yang umum digunakan untuk analisa oleh pihak eksternal adalah neraca, laporan laba rugi dan laporan arus kas. Laporan arus kas sangat penting untuk mengindikasikan kondisi perusahaan, karena dapat diketahui arus kas yang dihasilkan perusahaan. Beberapa akun yang dilaporkan pada neraca dan laporan laba rugi berupa akun non kas atau accrual basis (dasar akrual), sedangkan laporan arus kas menggunakan cash basis.

Laporan arus kas bertujuan untuk melaporkan penerimaan dan pengeluaran kas selama satu periode yang berasal dari aktivitas operasi, 
investasi, dan pendanaan. Dengan tersedianya informasi laporan laba dan laporan arus kas, maka stakeholder, terutama pihak investor dapat melakukan penilaian terhadap kemampuan perusahaan dalam menghasilkan kas dan setara kas serta menilai kebutuhan perusahaan untuk menggunakan arus kas tersebut.

Dalam kegiatan pasar modal, pentingnya arus kas erat kaitannya dengan pengambilan keputusan karena laporan arus kas memuat informasi tentang aktifitas operasional, investasi dan pendanaan yang sangat membantu pengambilan keputusan investor. Hal ini dapat diamati dari aktivitas yang terjadi di pasar modal seperti tercermin dalam perubahan demand dan supply surat-surat berharga yang diperdagangkan di pasar modal.

Aktivitas operasional meliputi semua transaksi yang yang berkaitan dengan laba yang dilaporkan dalam laporan laba rugi. Laporan laba rugi yang berasal dari bukan kegiatan operasional seperti penjualan peralatan atau aktiva lainnya tidak termasuk dalam aktivitas ini. Aktivitas investasi meliputi transaksi kas yang berhubungan dengan perolehan fasilitas investasi dan non kas lainnya yang digunakan oleh perusahaan dan kas yang diterima dari hasil atau pengembalian investasi yang dilakukan sebelumnya. Aktivitas pendanaan menyangkut bagaimana kegiatan kas diperoleh untuk membiayai termasuk operasinya, arus kas masuk merupakan kegiatan mendapatkan dana untuk kepentingan perusahaan dan arus kas keluar adalah pembayaran kembali kepada pemilik dan kreditur atas dana yang diberikan sebelumnya.

Pembayaran dividen merupakan salah satu kebijakan penting yang berhubungan dengan arus kas dimana dividen adalah bagian keuntungan perusahaan yang dibayar kepada pemegang saham atau investor. Kebijakan pembayaran dividen melibatkan arus kas keluar (cash outflow) yang relatif besar sehingga dalam prosesnya, kebijakan tersebut harus ditetapkan dengan mempertimbangkan kemampuan perusahaan menghasilkan dana kas dan kebutuhan perusahaan atas dana kas. Namun, dari data yang dikumpulkan diketahui bahwa beberapa Bank tetap melakukan pembayaran dividen kepada pemegang saham, walaupun arus kas dari aktivitas operasi dan arus kas dari aktivitas investasi turun. Dan beberapa bank lainnya tidak membayar dividen kepada pemegang saham walaupun arus kas dari aktivitas operasi dan arus kas dari aktivitas investasi naik. Dalam penelitian ini, arus kas dari aktivitas pendanaan tidak digunakan, karena didalamnya termasuk pembayaran dividen. 
Penelitian yang menguji pengaruh arus kas terhadap pembayaran dividen pada perusahaan manufacturing di Bursa Efek Jakarta telah dilakukan oleh Mardiana dengan jumlah populasi sebanyak 153 perusahaan dengan sampel penelitian 29 perusahaan yang membayar dividen dan 31 perusahaan yang tidak membayar dividen. Dengan menggunakan analisis statistic uji beda dua rata-rata dibuktikan bahwa tidak ada perbedaan yang signifikan antara arus kas operasi dengan arus kas investasi antara perusahaan yang membayar dividen dan yang tidak membayar dividen.

Penelitian sejenis lainnya dilakukan oleh Andreas tentang pengaruh arus kas terhadap pembayaran dividen pada bank yang telah go public di Bursa Efek Jakarta. Populasi penelitian terdiri dari 333 perusahaan yang terdaftar pada Bursa Efek Jakarta periode 2003 -2004 dan sampel penelitian terdiri dari 9 bank yang membayar dividen tahun 2003 dan 10 bank tahun 2004, sedangkan bank yang tidak membayar dividen sebanyak 17 bank tahun 2003 dan 16 tahun 2004. Dengan menggunakan analisis statistic uji beda dua rata-rata terbukti bahwa ada perbedaan signifikan arus kas aktivitas operasi antara bank yang membayar dividen dengan bank yang tidak membayar dividen.

Berdasarkan uraian diatas, dapat dirumuskan masalah penelitian sebagai berikut; Apakah ada perbedaan arus kas dari aktivitas operasi dan arus kas dari aktivitas investasi antara Bank yang membayar dividen dengan Bank yang tidak membayar dividen pada Bank yang terdaftar di Bursa Efek Indonesia.

\section{TELAAH TEORI}

\section{Laporan Arus Kas}

Informasi tentang arus kas suatu perusahaan berguna bagi para pemakai laporan keuangan sebagai dasar perusahaan dalam menghasilkan kas dan setara kas dan menilai kebutuhan untuk menggunakan arus kas tersebut. Dalam pengambilan keputusan ekonomi, para pemakai perlu melakukan evaluasi terhadap kemampuan perusahaan dalam menghasilkan kas dan setara kas serta kepastian perolehannya.

Laporan arus kas harus melaporkan arus kas selama periode tertentu dan diklasifikasi menurut aktivitas operasi, investasi dan pendanaan (PSAK No. 2, 2007;paragraph 9 dan 10). Perusahaan menyajikan arus kas dari aktivitas operasi, investasi dan pendanaan dengan cara yang paling sesuai dengan bisnis perusahaan tersebut. Klasifikasi menurut aktivitas memberikan informasi yang memungkinkan para 
pengguna laporan untuk menilai pengaruh aktivitas tersebut terhadap posisi keuangan perusahaan serta terhadap jumlah kas dan setara kas.

Menurut Erhans dan Yusuf (2000; 42) Laporan arus kas adalah laporan yang memuat informasi mengenai ringkasan penerimaan dan pengeluaran kas suatu usaha yang terjadi selama satu periode, seperti satu bulan, atau satu semester atau satu tahun. Lebih lanjut, simamora (2000; 488) menyatakan bahwa: Laporan arus kas adalah laporan keuangan yang memperlihatkan pengaruh dari aktivitas-aktivitas operasi, pendanaan dan investasi perusahaan terhadap arus kas selama periode akuntansi tertentu dalam suatu cara yang merekonsiliasi saldo awal dan akhir kas.

Bertitik tolak dari pengertian tersebut, berarti laporan arus kas terdiri dari laporan arus kas dari aktivitas operasi, aktivitas investasi dan aktivitas pendanaan yang dilakukan perusahaan dalam suatu periode tertentu.

\section{Konsep Dasar Laporan Arus Kas}

Laporan arus kas merupakan laporan keuangan dasar yang berisi mengenai aliran kas masuk dan aliran kas keluar perusahaan.

Menurut Munawir (2004;159), sumber penerimaan kas (aliran kas masuk ) dalam suatu perusahaan pada dasarnya dapat berasal :

- Hasil penjualan investasi jangka panjang, aktiva tetap baik yang berwujud maupun yang tidak berwujud (intangible asset); atau adanya penurunan aktiva tidak lancar yang diimbangi dengan penambahan kas.

- Penjualan atau adanya emisi saham maupun adanya penambahan modal oleh pemilik perusahaan dalam bentuk kas.

- Pengeluaran surat tanda bukti baik jangka pendek (wesel) maupun hutang jangka panjang (hutang obligasi, hutang hipotik atau hutang jangka panjang yang lain) serta bertambahnya hutang yang diimbangi dengan penerimaan kas.

- Adanya penurunan atau berkurangnya aktiva lancar selain kas yang diimbangi dengan adanya penerimaan kas ; misalnya adanya penurunan piutang karena adanya penerimaan pembayaran, berkurangnya persediaan barang dagangan karena adanya penjualan secara tunai, adanya penurunan surat berharga (efek) karena adanya penjualan dan sebagainya.

- Adanya penerimaan kas karena sewa, bunga atau dividen dari investasinya, sumbangan atau hadiah maupun adanya pengembalian kelebihan pembayaran pajak pada periode-periode sebelumnya. 
Sedangkan penggunaan atau pengeluaran kas (aliran kas keluar) dapat disebabkan adanya transaksi-transaksi sebagai berikut :

- Pembelian saham atau obligasi sebagai investasi jangka pendek maupun jangka panjang serta adanya pembelian aktiva tetap lainnya.

- Penarikan kembali saham yang beredar maupun adanya pengambilan kas perusahaan oleh pemilik perusahaan.

- Pelunasan atau pembayaran angsuran hutang jangka pendek maupun hutang jangka panjang.

- Pembelian barang dagangan secara tunai, adanya pembayaran biaya operasi yang meliputi upah dan gaji, pembelian suplai kantor, pembayaran sewa, bunga, premi asuransi, advertensi dan adanya persekot-persekot biaya maupun persekot pembelian.

- Pengeluaran kas untuk pembayaran dividen (bentuk pembagian laba lainnya secara tunai), pembayaran pajak, denda-denda dan lain sebagainya.

Proses aliran kas masuk dan aliran kas keluar akan terjadi secara terus-menerus dalam perusahaan atau akan berlangsung terus selama hidupnya perusahaan.

\section{Klasifikasi Laporan Arus Kas}

Didalam laporan arus kas, arus kas masuk dan arus kas keluar harus diklasifikasikan ke dalam tiga kategori menurut sumber dan penggunaannya terkait dengan aktivitas perusahaan, yakni: aktivitas operasi, aktivitas investasi, dan aktivitas pendanaan. Pengklasifikasian arus kas memberikan informasi bagi pengguna laporan keuangan untuk menilai pengaruh aktivitas tersebut terhadap posisi dan kondisi keuangan perusahaan, ketersediaan kas, serta evaluasi hubungan diantara aktivitas itu sendiri.

Simamora (2000; 490) menjelaskan mengenai pengklasifikasian laporan arus kas sebagai berikut: laporan arus kas mengklasifikasikan penerimaan kas (cash receipts) dan pengeluaran kas (cash disbursement) berdasarkan aktivitas-aktivitas operasi, investasi, dan pendanaan. Klasifikasi menurut aktivitas ini memberikan informasi yang memungkinkan para pengguna laporan keuangan untuk menilai pengaruh aktivitas tersebut terhadap posisi keuangan perusahaan serta terhadap jumlah kas dan setara kas.

Menurut Harahap (2002;95-96), pengklasifikasian arus kas adalah sebagai berikut :

1) Kegiatan Operasional 
Semua transaksi yang berkaitan dengan laba yang dilaporkan dalam laporan laba rugi di kelompokan dalam golongan ini. Demikian juga arus kas masuk lainnya yang berasal dari kegiatan operasional misalnya:

- Penerimaan dari langganan

- Penerimaan dari piutang bunga

Arus kas keluar misalnya dari:

- Kas yang dibayarkan untuk pembelian barang dan jasa yang akan dijual

- Bunga yang dibayar atas utang perusahaan

- Pembayaran PPh

- Pembayaran gaji

Laporan laba rugi yang berasal dari bukan kegiatan operasional seperti penjualan peralatan atau aktiva tetap lainnya tidak termasuk sebagai kelompok kegiatan operasional. Kas yang diterima dalam kegiatan ini dimasukkan sebagai kegiatan investasi atau pendanaan, mana yang lebih dominan

2) Kegiatan Investasi

Disini dikelompokkan transaksi kas yang berhubungam dengan perolehan fasilitas investasi dan non kas lainnya yang digunakan oleh perusahaan. Arus kas masuk terjadi jika kas diterima dari hasil atau pengembalian investasi yang dilakukan sebelumnya.

Arus kas masuk misalnya dari:

- Penjualan aktiva tetap

- Penjualan surat berharga yang berupa investasi

- Penagihan pinjaman jangka panjang (tidak termasuk bunga jika ini merupakan kegiatan investasi)

- Penjualan aktiva lainnya yang digunakan dalam kegiatan produksi (tidak termasuk persediaan)

Arus kas keluar dari kegiatan ini adalah:

- Pembayaran untuk mendapatkan aktiva tetap

- Pembelian investasi jangka panjang

- Pemberian pinjaman pada pihak lain

- Pembayaran untuk aktiva lain yang digunakan dalan kegiatan produksi seperti hak paten (tidak termasuk persediaan yang merupakan persediaan operasional) 
3) Kegiatan Pendanaan

Kelompok ini menyangkut bagaimana kegiatan kas diperoleh untuk membiayai termasuk operasinya. Dalam kategori ini arus kas masuk merupakan kegiatan mendapatkan dana untuk kepentingan perusahaan. Arus kas keluar adalah pembayaran kembali kepada pemilik dan kreditur atas dana yang diberikan sebelumnya.

Arus kas masuk misalnya adalah sebagai berikut:

- Pengeluaran saham

- Pengeluaran wesel

- Pengeluaran obligasi

- Pengeluaran hipotek, dll

Arus kas keluar misalnya:

- Pembayaran dividen pembayaran lainnya yang diberikan kepada pemilik

- Pembelian saham pemilik kembali

- Pembayaran utang pokok dana yang dipinjam (tidak termasuk bunga karena dianggap sebagai kegiatan operasional)

\section{Dividen.}

Setiap investor yang menanamkan modalnya kedalam suatu perusahaan mengharapkan memperoleh dividen sebagai balas jasa atas modal yang ditanamkannya kedalam perusahaan tersebut. Pengertian dividen menurut Ahmad (2004:191) adalah: pembayaran laba perusahaan kepada pemegang sahamnya. Sedangkan PSAK No.23 (2007:Paragraf 4) mendifinisikan dividen sebagai: Distribusi laba kepada pemegang investasi ekuitas sesuai dengan proporsi mereka dari jenis modal tertentu.

Dari pengertian diatas dapat disimpulkan bahwa dividen adalah pembagian kekayaan atau aktiva kepada pemegang saham berdasarkan proporsi saham yang dimiliki. Dividen untuk saham biasa dinyatakan dalam satuan uang, sedangkan dividen untuk saham preferen dinyatakan dalam persentase dari nilai nominal.

Kebijaksanaan perusahaan yang membagi keuntungan (laba) kepada para pemegang saham membawa arti dalam dua hal, yaitu: dana yang dibagikan kepada para pemegang saham dan dana untuk membelanjai kebutuhan perkembangan usaha atau ekspansi perusahaan (hal ini tercermin dalam rencana pada pos laba yang ditahan). Dividen dapat dibayarkan dalam bentuk tunai atau saham, biasanya pembayaran dilakukan setiap triwulan dan hanya dapat dibayarkan dari laba yang ditahan bukan dari modal yang ditanam. Pada umumnya berlaku, semakin 
mantap profitabilitas perusahaan, semakin teratur pula pembayaran dividennya.

\section{Kebijakan Dividen}

Setiap perusahaan menetapkan kebijakan pembayaran dividen terhadap investor, hal ini akan mempengaruhi jumlah dividen yang diterima oleh investor. Perusahaan harus memilih apakah dividen akan dibayar saat ini atau ditunda hingga periode berikutnya. Brigham dan Houston (2000:6), mengatakan bahwa kebijakan dividen adalah kebijakan yang menciptakan keseimbangan diantara dividen saat ini dan pertumbuhan dimasa mendatang yang memaksimumkan harga saham".

Ahmad (2004:194) menguraikan beberapa kebijakan dasar yang dapat dipilih (dianut) perusahaan sehubungan dengan saat pembayaran dan jumlah nominal dividen yang akan dibayarkan, yaitu:

a. Dividen per saham stabil, perusahaan membayar dividen dalam jumlah yang tetap pada setiap periode, walaupun perusahaan tersebut mengalami kerugian.

b. Dividen Payout (DPO) yang stabil, rasio dividen dengan laba bersih stabil, tetapi jumlah nominal dividen yang dibayarkan bervariasi.

c. Dividen kombinasi, selain jumlah pembayaran dividen yang tetap perusahaan dapat membayar dividen tambahan jika keuntungan perusahaan meningkat.

d. Dividen Residual, dividen yang dibayarkan adalah residu (sisa) laba setelah dana untuk kebutuhan investasi terpenuhi. Dalam hal ini jika dalam suatu periode perusahaan mengalami kerugian maka dividen tidak akan dibayar.

Menurut Riyanto $(2001 ; 267)$ faktor-faktor yang mempengaruhi kebijakan dividen suatu perusahaan adalah sebagai berikut :

a. Posisi likuiditas Perusahaan

Posisi kas atau likuiditas dari suatu perusahaan merupakan fektor yang penting yang harus dipertimbangkan sebelum mengambil keputusan untuk menetapkan besarnya dividen yang akan dibayarkan kepada para pemegang saham. Oleh karena dividen merupakan cash outflow, maka semakin kuatnya posisi likuiditas perusahaan berarti makin besar kemampuan untuk membayar dividen.

b. Kebutuhan dana untuk membayar utang

Perusahaan akan memperoleh utang baru dengan menjual obligasi baru untuk membiayai perluasan perusahaan, sebelumnya harus 
direncanakan bagaimana caranya untuk membayar kembali utang tersebut. Utang dapat dilunasi pada hari jatuh tempo dengan mengganti utang tersebut dengan utang yang baru. Alternatif lain ialah perusahaan harus menyediakan dana sendiri yang berasal dari keuntungan untuk melunasi utang tersebut. Apabila perusahaan menetapkan bahwa pelunasan utangnya akan diambil dari laba ditahan, berarti perusahaan harus menahan sebagian besar dari pendapatannya untuk keperluan tersebut, yang ini berarti bahwa hanya sebagian kecil saja dari pendapatan atau earning yang dapat dibayarkan sebagai dividen, dengan kata lain perusahaan harus menetapkan dividen payout ratio yang rendah.

c. Tingkat pertumbuhan perusahaan

Perusahaan yang makin cepat tingkat pertumbuhannya, makin besar kebutuhan akan dana untuk membiayai pertumbuhan tersebut. Dalam hal ini, perusahaan lebih senang menahan earningnya dari pada dibayarkan sebagai dividen kepada para pemegang saham. Dengan demikian dapatlah dikatakan makin cepat tingkat pertumbuhan perusahaan makin besar dana yang dibutuhkan, makin besar kesempatan untuk memperoleh keuntungan, makin besar bagian pendapatan yang ditahan dalam perusahaan sehingga semakin rendah dividen payout rationya. Apabila perusahaan telah mencapai tingkat pertumbuhan sedemikian rupa sehingga kebutuhan dana nya dapat dipenuhi dengan dana yang berasal dari pasar modal atau sumber dana ekstern lainnya, maka perusahaan dapat menetapkan dividen payout ratio yang tinggi.

\section{Analisis Perbandingan Laporan Arus Kas Antara Yang Membayar Dividen Dengan yang Tidak Membayar Dividen}

Laporan Arus kas merupakan salah satu indikator untuk mengetahui kinerja keuangan perusahaan disaat mengalami kenaikan atau penurunan yaitu melalui perbandingan antara periode berjalan dan periode sebelumnya. Hasil kinerja yang telah dicapai perusahaan juga dapat dilihat dari kemampuan perusahaan membayar dividen.

Dana yang dibayarkan perusahaan sebagai dividen kepada pemegang saham bersumber dari dana kas perusahaan, sedangkan dana kas bersumber dari aliran (arus) kas yang secara garis besar dibagi kedalam tiga aktivitas, yakni: aktivitas operasi, aktivitas investasi dan aktivitas pendanaan. Pembagian arus kas kedalam tiga aktivitas tersebut akan menginformasikan dengan jelas dan terperinci mengenai ketersediaan atau 
kemampuan perusahaan menghasilkan kas. Jika arus kas masuk besar, maka ketersediaan kas juga besar, yang berarti kemampuan perusahaan untuk membayar Dividen juga besar. Hal ini dapat terlihat dari kenaikan arus kas dari aktivitas operasi, aktivitas investasi dan aktivitas pendanaan. Akan tetapi jika arus kas dari aktivitas operasi, aktivitas investasi dan aktivitas pendanaan turun, berarti kemampuan perusahaan dalam membayar dividen rendah karena ketersediaan kas yang kecil.

Namun pembayaran dividen tidak hanya didasarkan pada besar nya kas yang dihasilkan tetapi juga kebutuhan perusahaan terhadap dana kas tersebut. Karena walaupun laporan arus kas dari aktivitas operasi, investasi dan pendanaan mengalami kenaikan perusahaan tetap tidak membayar dividen karena dana kas di gunakan untuk membayar utang ataupun untuk membiayai pertumbuhan perusahaan (ekspansi) dalam aktivitas investasinya. Seperti yang di kemukakan oleh Riyanto $(2001 ; 267)$ faktorfaktor yang mempengaruhi kebijakan dividen suatu perusahaan adalah Posisi likuiditas Perusahaan, kebutuhan dana untuk membayar utang, tingkat pertumbuhan perusahaan.

Sebaliknya perusahaan justru tetap membayar dividen walaupun laporan arus kas dari aktivitas operasi, investasi dan pendanaan turun dimana dividen dibayar dari laba ditahan. Hal ini tergantung pada kebijakan perusahaan, sehubungan dengan saat pembayaran dan jumlah nominal dividen yang akan dibayarkan. Menurut Ahmad (2004:194) ada 4 kebijakan dapat dipilih perusahaan yaitu : Dividen per saham stabil, dimana perusahaan membayar dividen dalam jumlah yang tetap pada setiap periode walaupun perusahaan tersebut mengalami kerugian. Dividen Payout (DPO) yang stabil,yaitu rasio dividen dengan laba bersih stabil, tetapi jumlah nominal dividen yang dibayarkan bervariasi, Dividen kombinasi, selain jumlah pembayaran dividen yang tetap perusahaan dapat membayar dividen tambahan jika keuntungan perusahaan meningkat, Dividen Residual,yaitu dividen yang dibayarkan adalah residu (sisa) laba setelah dana untuk kebutuhan investasi terpenuhi. Dalam hal ini jika dalam suatu periode perusahaan mengalami kerugian maka dividen tidak akan dibayar.

Penelitian sejenis terhadap perbandingan laporan arus kas aktivitas operasi dan investasi antara perusahaan yang membayar dividen dengan yang tidak membayar dividen dilakukan oleh Mardiana pada Perusahaan Manufaktur yang terdaftar di Bursa Efek Indonesia dengan menggunakan analisis Statistik Uji Beda Dua Rata-rata, dibuktikan bahwa tidak ada perbedaan signifikan antara arus kas aktivitas operasi dan arus kas aktivitas 
investasi antara perusahaan yang membayar dividen dengan yang tidak membayar dividen. Sedangkan penelitian sejenis yang dilakukan oleh Andreas Ginting pada Perusahaan Perbankan yang terdaftar di Bursa Efek Jakarta dengan menggunakan analisis Statistik Uji Beda Dua rata-rata, dibuktikan bahwa ada perbedaan yang signifikan antara aruskas aktivitas operasi dan arus kas aktivitas investasi antara Bank yang membayar dividen dengan yang tidak membayar dividen.

Berdasarkan uraian tersebut maka hipotesis yang dibangun adalah

Ha : Ada perbedaan arus kas dari aktivitas operasi dan arus kas dari aktivitas investasi antara bank yang membayar dividen dengan bank yang tidak membayar dividen pada bank yang terdaftar di Bursa Efek Indonesia".

\section{METODE PENELITIAN}

\section{Populasi dan Sampel}

Populasi dalam penelitian ini adalah seluruh bank yang terdaftar dalam Bursa Efek Indonesia periode 2015 sebanyak 29 Bank. Sampel dalam penelitian ini adalah 15 bank yang melakukan pembayaran dividen dan 14 bank yang tidak melakukan pembayaran dividen tahun 2015 . Teknik pengambilan sampel yang digunakan dalam penelitian ini adalah total sampling, yaitu: mengambil seluruh populasi menjadi sampel penelitian. Berdasarkan kriteria di atas, sampel terpilih sebanyak 29 perusahaan bank seperti tabel dibawah ini : 


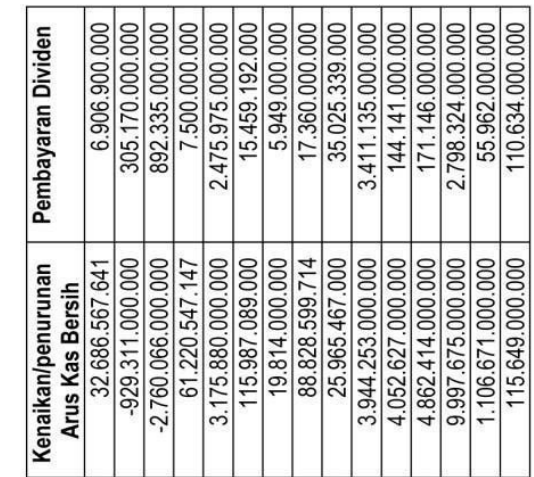

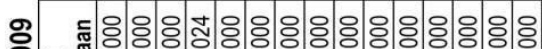

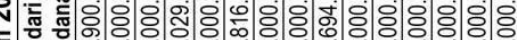
క ๘药

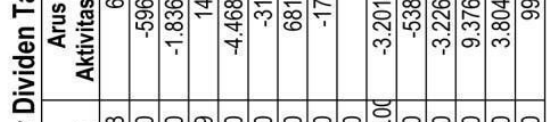

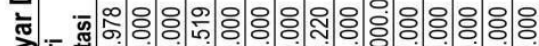

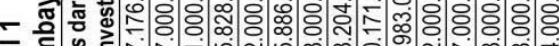
ब

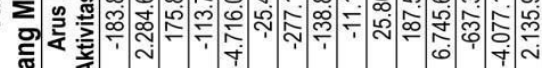

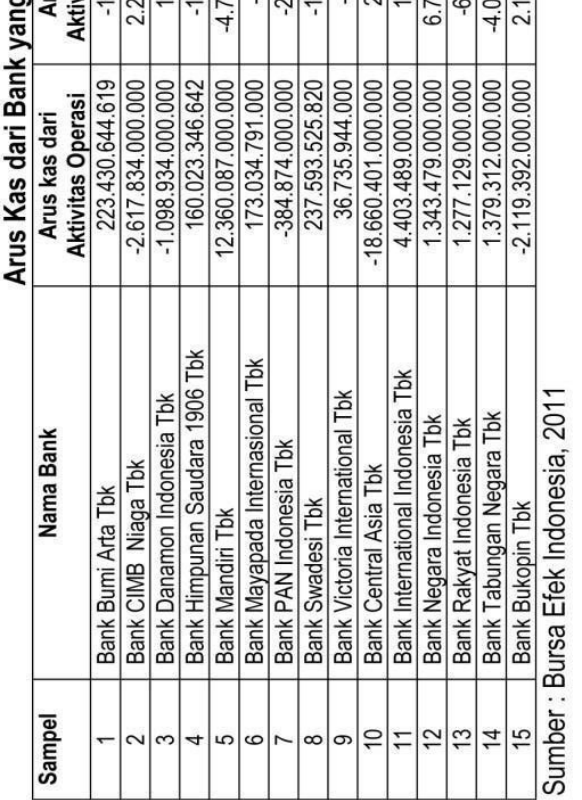

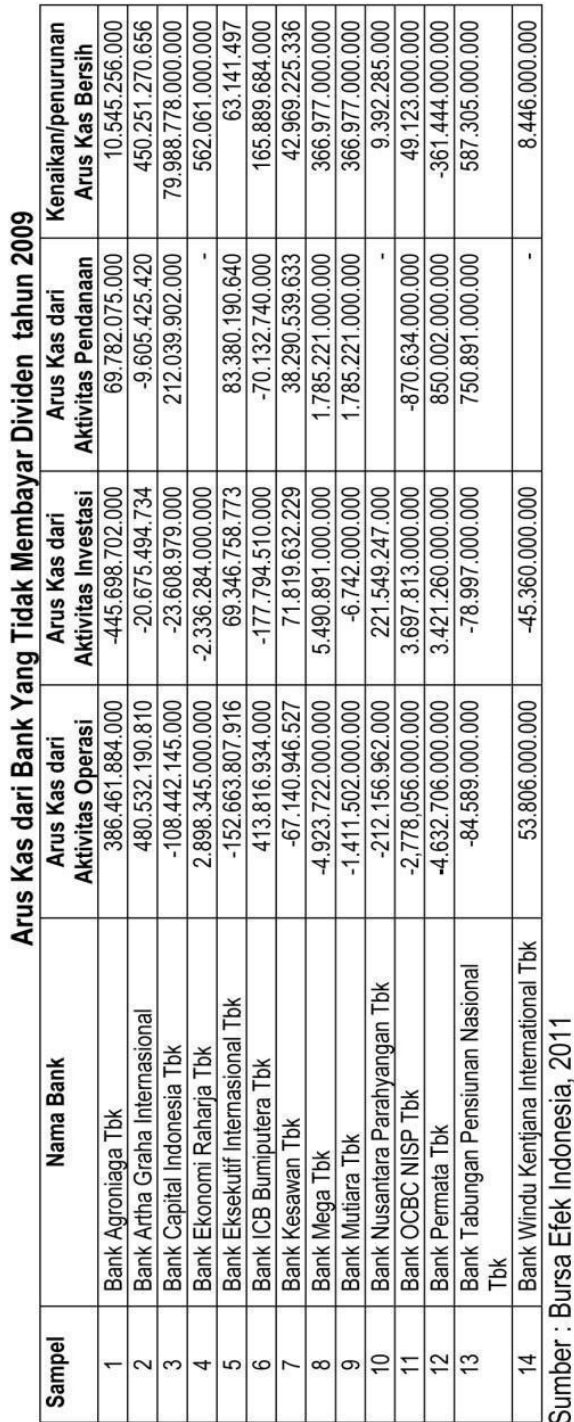




\section{Operasionalisasi Variabel}

Adapun variabel yang diteliti dalam penelitian ini adalah :

1. Aktivitas Operasional meliputi semua transaksi yang yang berkaitan dengan laba yang dilaporkan dalam laporan laba rugi. Laporan laba rugi yang berasal dari bukan kegiatan operasional seperti penjualan peralatan atau aktiva lainnya tidak termasuk dalam aktivitas ini.

2. Aktivitas investasi meliputi transaksi kas yang berhubungan dengan perolehan fasilitas investasi dan non kas lainnya yang digunakan oleh perusahaan dan kas yang diterima dari hasil atau pengembalian investasi yang dilakukan sebelumnya.

3. Pembayaran Dividen yaitu bagian keuntungan perusahaan yang dibayar kepada pemegang saham atau investor

\section{Teknik Pengumpulan Data}

Teknik pengumpulan data yang digunakan adalah teknik dokumentasi. Penulis mengumpulkan data laporan arus kas yang terdiri dari aktivitas operasi, arus kas dari aktivitas investasi dan pembayaran dividen pada Bank yang telah terdaftar di Bursa Efek Indonesia tahun 2011, yang diperoleh dari situs www.jsx.co.id.

\section{Teknik Analisis Data}

\section{a. Uji Beda Dua Rata-rata}

Analisis hipotesis dilakukan dengan uji beda dua rata-rata untuk mengetahui apakah ada perbedaan arus kas dari aktivitas operasi dan arus kas dari aktivitas investasi antara Bank yang membayar dividen dengan bank yang tidak membayar dividen pada Bank yang terdaftar di Bursa Efek Indonesia dengan langkah-langkah sebagai berikut :

1. $\mathrm{H}_{0}: \mu_{1}=\mu_{2}:$ tidak ada perbedaan arus kas dari aktivitas operasi dan arus kas dari aktivitas investasi antara Bank yang membayar dividen dengan Bank yang tidak membayar dividen pada Bank yang telah terdaftar di Bursa Efek Indonesia.

$\mathrm{H}_{1}: \mu_{1} \neq \mu_{2}:$ ada perbedaan arus kas dari aktivitas operasi dan arus kas dari aktivitas investasi antara Bank yang membayar dividen dengan Bank yang tidak membayar dividen pada Bank yang telah terdaftar di Bursa Efek Indonesia.

2. Jumlah sampel $=29$ dengan tingkat signifikansi $(\alpha)=5 \%$

3. Uji Beda Rata-rata 


$$
Z_{0}=\frac{\bar{X}_{1}-\bar{X}_{2}}{\sigma_{\bar{x}_{1}-\bar{x}_{2}}}, \quad \sigma_{\bar{x}_{1}-\bar{x}_{2}}=\sqrt{\frac{\sigma_{1}^{2}}{n_{1}}+\frac{\sigma_{2}^{2}}{n_{2}}}
$$

$\bar{X}_{1}$ = rata- rata arus kas dari aktivitas operasi dan arus kas dari aktivitas

investasi bank yang membayar deviden.

$\bar{X}_{2}=$ rata- rata arus kas dari aktivitas operasi dan arus kas dari aktivitas investasi bank yang tidak membayar deviden.

$\sigma_{\bar{x}_{1}-\bar{x}_{2}}=$ standar deviasi rata-rata arus kas dari aktivitas operasi dan aktivitas investasi Bank yang membayar dividen dan yang tidak membayar dividen

$\mathrm{n} \quad$ = Jumlah Sampel

4. Kriteria Pengujian

Ho diterima jika nilai signifikansi lebih besar dari $5 \%$

Ho ditolak jika nilai signifikansi lebih kecil dari 5\%

\section{b. Analisis Regresi Logistik}

Penelitian ini terdiri dari 2 variabel independent X1 (arus kas aktivitas operasional) dan X2 (arus kas aktivitas investasi) dan 1 varibel dependen (pembayaran dividen). Untuk memenuhi kriteria persyaratan regresi logistik, maka variabel dependen Y (pembayaran dividen) harus varibel dummy dengan 2 alternatif yakni membayar dividen (diberi skor 1) dan tidak membayar dividen (diberi skor 0 ).

Adapun rumus persamaan regresi logistik adalah sebagai berikut :

$$
\ln \left(\frac{\pi}{1-\pi}\right)=\exp \text { bo }+b_{1} X_{1}+b_{2} X_{2}
$$

dimana :

bo $\quad=$ koefisien regresi konstanta

b1 = koefisien regresi $\mathrm{X} 1$

b2 = koefisien regresi $\mathrm{X} 2$

$\mathrm{X} 1=$ Arus kas aktivitas operasional

$\mathrm{X} 1=$ Arus kas aktivitas investasi

$\ln \left(\frac{\pi}{1-\pi}\right)=\mathrm{Y}=$ pembayaran dividen

Jika p-value $<0.05$, maka Ho ditolak atau Ha diterima, berarti variable independent memiliki pengaruh signifikan terhadap variable dependen (pembayaran dividen). Sebaliknya jika p-value $>0.05$, berarti variable 
independent tidak memiliki pengaruh signifikan terhadap variable dependen (pembayaran dividen).

\section{HASIL PENELITIAN DAN PEMBAHASAN}

\section{Pengujian Hipotesis}

\section{a. Uji Beda dua rata-rata Arus Kas Aktivitas Operasional}

Uji beda dilakukan untuk mengetahui apakah ada perbedaan yang signifikan arus kas aktivitas operasional antara bank yang membayar dividen dengan bank yang tidak membayar dividen dengan menggunakan Independent-Sampel T-Test (Uji-T) dengan hasil sebagai berikut :

\section{Tabel 3}

\section{Hasil Uji Beda}

\begin{tabular}{|rr|r|c|c|r|}
\hline \multicolumn{2}{|c|}{ X1 } & $\mathrm{N}$ & Mean & Std. Deviation & \multicolumn{1}{c|}{ Std. Error Mean } \\
\hline Aktivitas & 1.00 & 15 & $-219141383194,60$ & 6198243497863,83 & 1600379589531,00 \\
Operasi & .00 & 14 & $-724144060902,36$ & 2096152125472,91 & 560220220291,26 \\
\hline
\end{tabular}

Sumber : Data sekunder diolah 2016

Dari hasil pengujian diatas diketahui bahwa table group statistic menunjukkan ringkasan dari rata-rata dan standar deviasi arus kas operasi bank yang membayar dividen dengan yang tidak membayar dividen. Ratarata arus kas operasi bank yang membayar dividen adalah sebesar Rp 219.141.383.194,60 dengan standar deviasi $\mathrm{Rp}$ 6.198.243.497.863,83. Sedangkan rata-rata arus kas dari aktifitas operasi bank yang tidak membayar dividen adalah sebesar Rp -724.144.060.902,36 dengan standar deviasi Rp 2.096.152.125.472,91.

Selanjutnya untuk mengetahui apakah ada perbedaan yang signifikan arus kas operasi antara bank yang membayar dividen dengan yang tidak membayar dividen, dilakukan uji Levene's test dengan hasil sebagai berikut :

\section{Tabel 4}

Hasil Uji Signifikansi

Independent Samples Test

\begin{tabular}{|ll|r|r|r|r|r|r|}
\hline \multirow{2}{*}{} & \multicolumn{2}{|c|}{$\begin{array}{l}\text { Levene's Test } \\
\text { for Equality of } \\
\text { Variances }\end{array}$} & \multicolumn{5}{c|}{ t-test for Equality of Means } \\
\cline { 2 - 8 } & F & Sig. & \multicolumn{1}{c|}{ t } & Df & Sig. (2-tailed) & Mean Difference \\
\hline $\begin{array}{l}\text { Aktivitas } \\
\text { Operasi }\end{array}$ & $\begin{array}{l}\text { Equal } \\
\text { variances } \\
\text { assumed }\end{array}$ & 1.252 & .272 & .289 & 27 & .774 & 505002677707.76 \\
\hline
\end{tabular}




\begin{tabular}{|l|l|l|l|l|l|}
\hline $\begin{array}{l}\text { Equal } \\
\text { variances not } \\
\text { assumed }\end{array}$ & & .297 & 17.360 & .769 & 505002677707.76 \\
\hline
\end{tabular}

Sumber : Data sekunder diolah 2016

Berdasarkan output Independent Samples Test diatas dapat dilihat bahwa nilai signifikansi untuk perbedaan arus kas operasi bank yang membayar dividen dengan bank yang tidak membayar dividen adalah sebesar 0,774 > sig- $\alpha(0.05)$, hal ini berarti bahwa tidak ada perbedaan signifikan dari aktivitas operasional antara bank yang membayar dividen dengan yang tidak membayar dividen.

\section{b. Uji Beda dua rata-rata Arus Kas Aktivitas Investasi}

Uji beda dilakukan untuk mengetahui apakah ada perbedaan arus kas aktivitas investasi antara bank yang membayar dividen dengan bank yang tidak membayar dividen dengan menggunakan Independent-Sampel T-Test (Uji-T)dengan hasil sebagai berikut :

\section{Tabel 5}

Hasil Uji Beda

\begin{tabular}{|rr|r|r|r|r|}
\hline \multicolumn{2}{|c|}{ X2 } & $\mathrm{N}$ & Mean & Std. Deviation & \multicolumn{1}{c|}{ Std. Error Mean } \\
\hline Aktivitas & 1.00 & 15 & 1810323715552.20 & 7129192209578.94 & 1840749513307.39 \\
Investasi & .00 & 14 & 702679925162.00 & 2045124756100.83 & 546582582181.35 \\
\hline
\end{tabular}

Sumber : Data primer diolah 2016

Dari hasil pengujian di atas diketahui bahwa table group statistic menunjukkan ringkasan rata-rata dan standar deviasi dari aktivitas investasi bank yang membayar dividend an yang tidak membayar dividen. Rata-rata arus kas dari Bank yang membayar dividen adalah sebesar Rp 1.810.323.715.552,20 dengan standar deviasi Rp 7.129.192.209.578,94. Sedangkan rata-rata arus kas dari aktivitas investasi bank yang tidak membayar dividen sebesar Rp 702.679.925.162,00 dengan standar deviasi Rp 2.045.124.756.100,83.

Selanjutnya untuk mengetahui apakah ada perbedaan yang signifikan arus kas investasi antara bank yang membayar dividen dengan yang tidak membayar dividen, dilakukan uji Levene's test dengan hasil sebagai berikut : 
Tabel 6

Hasil Uji Signifikansi

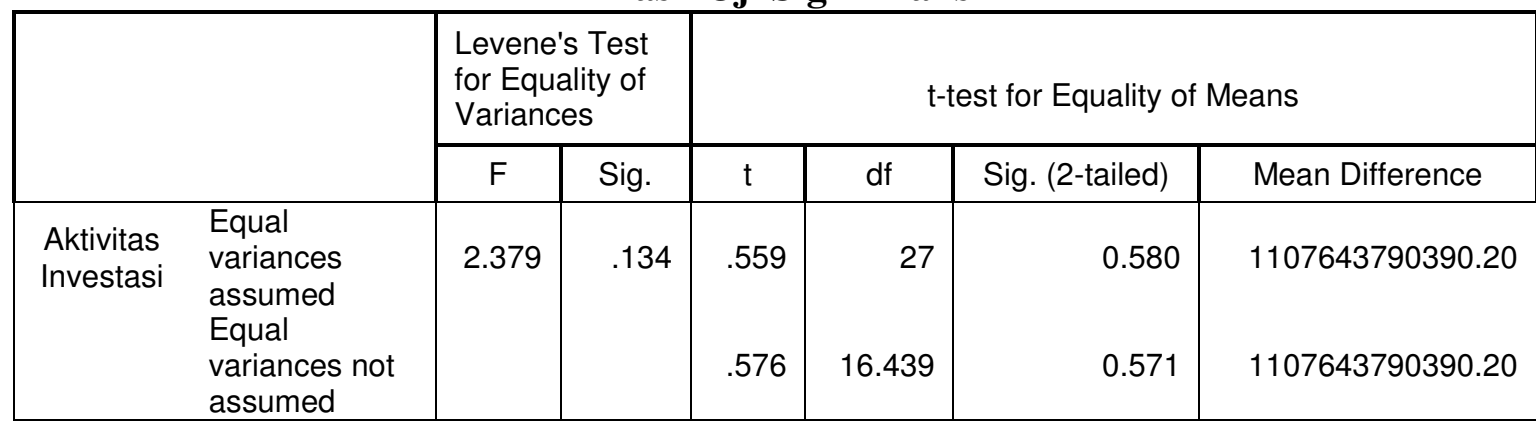

Sumber : Data primer diolah 2016

Berdasarkan output Independent Samples Test diatas dapat dilihat bahwa nilai signifikansi untuk perbedaan arus kas investasi bank yang membayar dividen dengan bank yang tidak membayar dividen adalah sebesar 0,580 > sig- $\alpha$ (0.05), hal ini berarti bahwa tidak ada perbedaan signifikan dari aktivitas investasi antara bank yang membayar dividen dengan yang tidak membayar dividen.

\section{c. Uji Pengaruh dengan Regresi Logistik}

Analisis pengaruh dilakukan dengan analisis regresi logistik dengan hasil sebagai berikut :

Tabel 7

Konstanta Koefisien Regresi

Variables in the Equation

\begin{tabular}{|c|c|c|c|c|c|c|}
\hline & B & S.E. & Wald & df & Sig. & $\operatorname{Exp}(B)$ \\
\hline Step 0 Constant & .069 & .372 & .034 & $\overline{1}$ & .853 & 1.071 \\
\hline
\end{tabular}

Dari tabel di atas diketahui bahwa nilai bo $=0.069$ atau $\exp ($ bo $)=$ $\exp (0.069)=1.071$. Nilai ini sama dengan odd Ratio yakni perbandingan antara bank yang membayar dividen 15 dan bank yang tidak membayar dividen 14 yakni : Odd ratio $=15 / 14=1.071$.

\section{d. Uji-F secara simultan}

Uji regresi logistik variabel independent X1 (arus kas aktivitas operasional) dan $\mathrm{X} 2$ (arus kas aktivitas investasi) terhadap variabel dependen Y (pembayaran dividen) memberikan hasil berikut : 
Tabel 7

Hasil Uji Pengaruh Simultan

Omnibus Tests of Model Coefficients

\begin{tabular}{|rl|r|r|r|}
\hline & & Chi-square & df & \multicolumn{1}{c|}{ Sig. } \\
\hline Step 1 & Step & 1.608 & 2 & .447 \\
& Block & 1.608 & 2 & .447 \\
& Model & 1.608 & 2 & .447 \\
\hline
\end{tabular}

Sumber : Data sekunder diolah 2016

Dari tabel di atas terlihat bahwa nilai koefisien signifikansi chisquare $=0.447$, lebih besar dari sig- $\alpha(0.05)$, sehingga dapat disimpulkan bahwa hasil uji regresi logistik tidak signifikan. Dengan kata lain, arus kas aktivitas operasional dan arus kas aktivitas investasi tidak berpengaruh signifikan terhadap pembayaran dividen jika pengujian dilakukan secara simultan.

\section{e. Uji t Secara Parsial}

Uji pengaruh parsial masing masing X1 (arus kas aktiitas operasional) dan X2 (arus kas investasi) memberi hasil sebagai berikut :

\section{Tabel 8}

Hasil Perhitungan Koefisien Model Regresi Logistik Binary

Variables in the Equation

\begin{tabular}{|ll|r|r|r|r|r|r|}
\hline & & \multicolumn{1}{|c|}{ B } & \multicolumn{1}{c|}{ S.E. } & Wald & df & \multicolumn{1}{c|}{ Sig. } & \multicolumn{1}{c|}{$\operatorname{Exp}(\mathrm{B})$} \\
\hline Step & X1 & .103 & .369 & .078 & 1 & .780 & 1.108 \\
1 & X2 & .159 & .283 & .315 & 1 & .575 & 1.172 \\
& Constant & -6.931 & 6.471 & 1.147 & 1 & .284 & .001 \\
\hline
\end{tabular}

a. Variable(s) entered on step 1: X1, X2.

Sumber : Data sekunder diolah 2016

Dari tabel di atas terlihat bahwa nilai sig-p X1 $=0.780$ dan sig-p X2 $=0,575$, lebih besar dari sig- $\alpha(0.05)$, sehingga dapat disimpulkan bahwa secara parsial arus kas aktivitas operasi dan arus kas aktivitas investasi tidak berpengaruh signifikan terhadap variable dependen pembayaran dividen.

\section{f. Uji Determinasi $R$}

Untuk mengetahui besarnya pengaruh arus kas dari aktivitas operasional dan arus kas dari aktivitas investasi terhadap pembayaran dividen dapat dilihat dari model summary berikut ; 
Tabel 9

Hasil Uji Determinasi R

Model Summary

\begin{tabular}{|l|r|r|r|}
\hline Step & $\begin{array}{c}-2 \text { Log } \\
\text { likelihood }\end{array}$ & $\begin{array}{c}\text { Cox \& Snell } \\
\text { R Square }\end{array}$ & $\begin{array}{c}\text { Nagelkerke } \\
\text { R Square }\end{array}$ \\
\hline 1 & $38.560^{\mathrm{a}}$ & .054 & .072 \\
\hline
\end{tabular}

a. Estimation terminated at iteration number 4 because parameter estimates changed by less than .001 .

Sumber : Data primer diolah 2016

Dari tabel di atas terlihat bahwa nilai R-square Cox \& Snell = 0.054, sehingga besarnya pengaruh arus kas dari aktivitas operasional dan arus kas dari aktivitas investasi terhadap pembayaran dividen dapat dikalkulasikan sebagai berikut : $\mathrm{K}=\mathrm{R}$-square $\mathrm{x} 100 \%=0.054 \times 100 \%=$ $5.4 \%$. Dengan demikian, dapat disimpulkan bahwa pengaruh arus kas dari aktivitas operasi dan arus kas dari aktivitas investasi terhadap pembayaran dividen sangat kecil yaitu hanya 5,4\% .

\section{g. Persamaan Regresi Logistik}

Persamaan regresi logistik dapat disusun berdasarkan nilai koefisien masing masing variable. Berdasarkan nilai koefisien masing masing variabel tersebut di atas pada tabel 8 di atas, maka persamaan regresi logistik dalam penelitian ini dapat disusun sebagai berikut :

$$
\ln \left(\frac{\pi}{1-\pi}\right)=\exp \left(-6.931+0.103 \mathrm{X}_{1}+0.159 \mathrm{X}_{2}\right)
$$

Selanjutnya, untuk mengetahui pengaruh lebih dominant diantara kedua variabel arus kas dari aktivitas operasi dan arus kas dari aktivitas investasi, dapat dikalkulasikan dari tabel berikut :

\section{Tabel 10}

Perhitungan Dominansi Pengaruh X1 dan X2

\begin{tabular}{ccc}
\hline Parameter & Koefisien & Persentase \\
\hline Aktivitas operasional & 0.103 & $39.31 \%$ \\
\hline Aktivitas investasi & 0.159 & $60.69 \%$ \\
\hline Total & 0.262 & $100.00 \%$ \\
\hline
\end{tabular}

Sumber : data sekunder diolah 2016

Hasil perhitungan di atas dilakukan berdasarkan besarnya nilai koefisien masing masing variabel dimana koefisien arus kas dari aktivitas 
operasi $\mathrm{X} 1=0.103$ dan variabel arus kas dari aktivitas investasi $=0.159$. Berdasarkan persentase masing masing, diketahui bahwa arus kas dari aktivitas operasional memiliki pengaruh sebesar $39.31 \%$ dan arus kas dari aktivitas investasi memiliki pengaruh sebesar $60.69 \%$ dari $5.4 \%$ keseluruhan pengaruh arus kas operasi dan investasi terhadap pembayaran dividen. Dengan demikian diperoleh pengaruh aktivitas operasi terhadap pembayaran dividen sebesar $12.2 \%$ dan pengaruh aktivitas investasi terhadap pembayaran dividen sebesar $3.28 \%$.

\section{Pembahasan}

\section{a. Arus Kas dari Aktivitas Operasi}

Berdasarkan penelitian terhadap 29 sampel perusahaan perbankan yang tercatat di Bursa Efek Indonesia, diketahui bahwa walaupun arus kas dari aktivitas operasi positif, namun beberapa bank tidak membayar dividen, sebaliknya terdapat beberapa bank dengan arus kas dari aktivitas operasi negatif tetap melakukan pembayaran dividen.

Secara teoritis, jika arus kas operasi meningkat, akan diikuti oleh peningkatan pembayaran dividen, karena perusahaan memiliki arus kas yang cukup hasil aktifitas operasionalnya untuk membayar dividen, tetapi sebaliknya, jika arus kas menurun, maka akan diikuti pula oleh penurunan kemampuan perusahaan untuk melakukan pembayaran dividen.

Berdasarkan analisis penulis, diketahui bahwa sebagian perusahaan dengan arus kas negatif atau rendah, mereka tetap melakukan pembayaran dividen, namun ada juga perusahaan dengan arus kas positif, tetapi tidak melakukan pembayaran dividen. Hal ini berarti tinggi rendahnya arus kas operasional tidak dijadikan sebagai pertimbangan utama dalam pembayaran dividen, tetapi juga kebutuhan terhadap kas tersebut. sekalipun pembayaran dividen merupakan tanggungjawab dan kewajiban perusahaan terhadap pemegang saham. Oleh karena itu, teori yang dikembangkan tidak didukung oleh hasil analisis, dimana arus kas aktifitas operasional memberi pengaruh negatif terhadap pembayaran dividen untuk perusahaan tertentu. Hal ini dapat disebabkan oleh faktorfaktor yang mempengaruhi perusahaan dalam membayar dividen suatu perusahaan yaitu posisi likuiditas perusahaan, kebutuhan dana untuk membayar utang dan tingkat pertumbuhan perusahaan.

Hasil pengujian hipotesis dengan uji beda membuktikan bahwa nilai koefisien Leveen's test $0.774>0.05$, sehingga dapat disimpulkan bahwa tidak ada perbedaan arus kas dari aktivitas operasi antara bank 
yang membayar dividen dengan bank yang tidak membayar dividen pada Bank yang terdaftar di Bursa Efek Indonesia (BEI).

Hasil pengujian hipotesis dengan regresi logistic jika di uji secara simultan membuktikan bahwa nilai koefisien signifikansi chi-square $=$ 0.447 , lebih besar dari sig- $\alpha$ (0.05), sehingga dapat disimpulkan bahwa hasil uji regresi logistik tidak signifikan. Dengan kata lain, arus kas aktivitas operasional dan arus kas aktivitas investasi tidak berpengaruh signifikan terhadap pembayaran dividen. Jika di uji secara parsial nilai signifikansi $=0.780$, lebih besar dari sig- $\alpha(0.05)$, sehingga dapat disimpulkan bahwa arus kas dari aktivitas operasi tidak mempunyai pengaruh yang signifikan terhadap pembayaran dividen.

Dengan demikian hipotesis ditolak dimana tidak ada perbedaan arus arus kas operasi antara bank yang membayar dividen dengan bank yang tidak membayar dividen diantara perusahaan perbankan yang terdaftar di Bursa Efek Indonesia.

Hasil penelitian ini sesuai dengan hasil penelitian oleh Mardiana dengan menggunakan analisis statistic uji beda dua rata-rata bahwa tidak ada perbedaan signifikan antara arus kas operasi dengan arus kas investasi antara perusahaan yang membayar dividen dan yang tidak membayar dividen. Tetapi, hasil penelitian ini berbeda dengan hasil penelitian Irawati (2010), yang membuktikan bahwa arus kas berpengaruh signifikan terhadap kebijakan pembayaran dividen bila diuji secara serentak dan hanya arus kas operasional yang berpengaruh signifikan terhadap dividen bila pengujian dilakukan secara parsial.

\section{Arus Kas dari Aktivitas Investasi}

Berdasarkan penelitian terhadap 29 sampel perusahaan perbankan yang terdaftar di Bursa Efek Indonesia, diketahui bahwa walaupun arus kas dari aktivitas investasi positif beberapa bank tidak membayar dividen, namun terdapat beberapa bank dengan arus kas dari aktivitas investasi negatif tetap melakukan pembayaran dividen.

Secara teoritis, jika arus kas investasi meningkat, akan diikuti oleh peningkatan pembayaran dividen, karena perusahaan memiliki arus kas yang cukup hasil aktifitas investasiya untuk membayar dividen, tetapi sebaliknya, jika arus kas menurun, maka akan diikuti pula oleh penurunan kemampuan perusahaan untuk melakukan pembayaran dividen. Tetapi, perusahaan-perusahaan dengan tingkat leverage (hutang jangka panjang) yang tinggi, cenderung untuk mempertahankan kebijakan 
dividen yang rendah guna menghindari adanya penurunan dividen atau bahkan tidak membayar dividen di masa masa yang akan datang.

Arus kas investasi merupakan bentuk penerimaan kas dari hasil penjualan aktiva tetap atau penjualan segmen pasar dan penjualan investasi jangka panjang lainya. Pola normal arus kas investasi adalah negatif, karena mengindikasikan bahwa perusahaan sedang melakukan pengembangan usaha untuk meningkatkan kegiatan operasi perusahaan. Jika arus kas bernilai negatif, jelas akan mengurangi kemampuan perusahaan untuk melakukan pembagian dividen tunai.

Berdasarkan analisis penulis, diketahui bahwa sebagian perusahaan dengan arus kas negatif atau rendah, tetap melakukan pembayaran dividen, namun ada juga perusahaan dengan arus kas positif, tetapi tidak melakukan pembayaran dividen. Hal ini berarti tinggi rendahnya arus kas investasi tidak dijadikan sebagai pertimbangan dalam pembayaran dividen, sekalipun pembayaran dividen merupakan tanggungjawab dan kewajiban perusahaan terhadap pemegang saham. Oleh karena itu, teori yang dikembangkan tidak didukung oleh hasil analisis, dimana arus kas aktifitas investasi memberi pengaruh negatif terhadap pembayaran dividen untuk perusahaan tertentu. Hal ini dapat disebabkan oleh faktor-faktor yang mempengaruhi perusahaan dalam membayar dividen suatu perusahaan yaitu posisi likuiditas perusahaan, kebutuhan dana untuk membayar utang dan tingkat pertumbuhan perusahaan.

Hasil pengujian hipotesis dengan uji beda membuktikan bahwa nilai koefisien Leveen's test $0.580>0.05$, sehingga dapat disimpulkan bahwa tidak ada perbedaan arus kas dari aktivitas operasi dan aktivitas investasi antara bank yang membayar dividen dengan bank yang tidak membayar dividen pada Bank yang terdaftar di Bursa Efek Indonesia (BEI)

Hasil pengujian hipotesis dengan regresi logistic membuktikan bahwa nilai koefisien signifikansi chi-square $=0.447$, lebih besar dari sig$\alpha(0.05)$, sehingga dapat disimpulkan bahwa hasil uji regresi logistik tidak signifikan. Dengan kata lain, arus kas aktivitas operasional dan arus kas aktivitas investasi tidak berpengaruh signifikan terhadap pembayaran dividen jika pengujian dilakukan secara simultan, jika di uji secara parsial nilai signifikansi $=0.575$, lebih besar dari sig- $\alpha(0.05)$, sehingga dapat disimpulkan bahwa arus kas dari aktivitas investasi tidak mempunyai pengaruh yang signifikan terhadap pembayaran dividen. Dengan demikian hipotesis ditolak dimana tidak ada perbedaan arus arus kas investasi antara perusahaan perbankan yang terdaftar di Bursa Efek Indonesia. 
Hasil penelitian ini sesuai dengan hasil penelitian sebelumnya oleh Anggada (2010), yang membuktikan bahwa arus kas tidak berpengaruh signifikan bila diuji secara simultan dan yang paling berpengaruh adalah arus kas investasi. Tetapi, hasil penelitian ini berbeda dengan hasil penelitian sebelumnya oleh Andreas Ginting dengan menggunakan analisis statistic uji beda dua rata-rata yang membuktikan bahwa ada perbedaan signifikan arus kas aktivitas operasi antara bank yang membayar dividen dengan bank yang tidak membayar dividen.

\section{KESIMPULAN DAN SARAN}

\section{Kesimpulan}

1. Tidak ada perbedaan arus kas dari aktivitas operasi dan aktivitas investasi antara bank yang membayar dividen dengan bank yang tidak membayar dividen pada Bank yang terdaftar di Bursa Efek Indonesia (BEI). Hal ini diindikasikan oleh nilai sig-p Levene Test $>0.05$.

2. Kedua variabel independent yaitu arus kas dara ativitas operasi dan arus kas dari ativitas investsi secara bersama sama tidak berpengaruh signifikan terhadap pembayaran dividen. Hal ini diindikasikan oleh nilai koefisien signifikansi chi-square $=0.447$, lebih kecil dari sig- $\alpha$ (0.05).

3. Variabel aktivitas operasional dan aktivitas investasi tidak memiliki pengaruh signifikan terhadap pembayaran dividen jika pengujian dilakukan secara parsial. Hal ini diindikasikan oleh nilai signifikansi $\mathrm{X} 1$ (arus kas operasional $)=0.780, \mathrm{X} 2($ arus kas investasi $)=0.575$ dan konstanta $=0.284$, seluruhnya lebih besar dari sig- $\alpha(0.05)$

4. Variabel aktivitas investasi memiliki pengaruh lebih besar dibandingkan variabel aktivitas operasi. Hal ini diindikasikan oleh persentase pengaruh dimana variabel X1 memiliki pengaruh sebesar $39.31 \%$ dan variabel X2 memiliki pengaruh sebesar $60.69 \%$.

\section{S a r a n}

Sebaiknya penelitian yang akan datang mengambil sampel pengamatan pada jenis perusahaan yang berbeda dengan tahun berbeda, bukan hanya pada perusahaan perbankan tetapi pada jenis perusahaan lain.

\section{DAFTAR PUSTAKA}

Ahmad, Kamarudin, 2004. Dasar-dasar Manajemen Investasi dan Portofolio, Edisi Revisi, Jakarta: Rineka Cipta 
Brigham F, Eguene dan Houston F, Joel 2000. Manajemen Keuangan, Buku Dua, Jakarta: Erlangga

Erhans, A dan Yusuf, Junaedi, 2000. Pengantar Akuntansi Berdasarkan Prinsip Akuntansi Indonesia: Perusahaan Jasa dan Dagang, Jakarta: Ercontara Rajawali

Gilang, Anggada, 2010. Pengaruh Arus Kas Terhadap Pembagian Dividen Tunai (Survey pada Perusahaan Makanan dan Minuman yang Terdaftar di BEI), Skripsi: Universitas Widyatama

Ginting Andreas,2006. Pengaruh Laporan Arus Kas Terhadap Pembayaran Dividen pada Bank yang Go Public di Bursa Efek Jakarta, Skripsi: Universitas Katolik Santo Thomas

Harahap, Sofyan Syafri, 2002. Teori Akuntansi: Laporan Keuangan, cetakan ketiga, Jakarta: Bumi Aksara

Irawati, Desi, 2010. Pengaruh Arus Kas terhadap Kebijakan Dividen pada Perusahaan Manufaktur yang go Publik di Indonesia, Skripsi: Universitas Muhammadyah Surakarta

Munawir, S, 2004. Analisis Laporan Keuangan, Cetakan Ketigabelas, Yogyakarta: Liberty

PSAK, 2007. Standar Akuntansi Keuangan-Ikatan Akuntansi Indonesia (SAK-IAI), Jakarta: Salemba Empat

Purba Mardiana, 2006. Analisis Perbandingan Arus Kas antara Perusahaan yang Membayar Dividen dengan yang tidak Membayar Dividen pada Perusahaan Manufaktur yang Tercatat di Bursa Efek Jakarta, Skripsi: Universitas Katolik Santo Thomas

Riyanto, Bambang, 2001. Dasar-dasar Pembelanjaan Perusahaan, Edisi Keempat, Cetakan Ketujuh, Yogyakarta: BPFE

Simamora, Henry, 2000. Akuntansi: Basis Pengambilan Keputusan Bisnis, jilid 2, Jakarta: Salemba Empat

Supranto, J. 1993. Statistik Teori dan Aplikasi. Jilid 2, Jakarta: Erlangga 